\title{
Analysis of Financial Performance in Predicting Financial Distress in Mining Companies
}

Diah Iskandar $^{1 *}$, Hendi Prihanto ${ }^{2}$

${ }^{1}$ Yenny Dwi Handayani Universitas Mercubuana Jakarta, Indonesia

${ }^{2}$ Islamiah Kamil Universitas Prof.Dr.Moestopo Beragama

DOI: 10.36348/sjef.2019.v03i12.004

| Received: 20.12.2019 | Accepted: 27.12.2019| Published: 30.12 .2019

*Corresponding author: Diah Iskandar

\section{Abstract}

This study aims to test the effect of Current ratio empirically, Return on Assets, Debt Ratio, Dividend Payout Ratio, and Price Book Value on Financial Distress. Causal correlation research methods. The sample selection in this study uses the Purposive Sampling method, so the criteria selected six mining sector companies. The data analysis method used in this study is the panel data regression method and found that the more appropriate model to use is the fixed effect. Based on the calculation results of the random effect model, the results of this study stated Current ratio, Return on Assets affect financial distress while Debt Ratio, Dividend Payout Ratio, Price Book Value do not affect financial distress.

Keywords: Financial Distress, Current Ratio, Return on Assets, Debt Ratio, Dividend Payout Ratio, Price Book Value.

Copyright @ 2019: This is an open-access article distributed under the terms of the Creative Commons Attribution license which permits unrestricted use, distribution, and reproduction in any medium for non-commercial use (NonCommercial, or CC-BY-NC) provided the original author and source are credited.

\section{INTRODUCTION}

The bankruptcy of a company can occur if it faces a problematic condition and is due to uncertainty regarding the ability of a company to continue its operations if its financial situation has decreased can be seen and measured from its financial statements.

Coal contributes $80 \%$ to the performance of the mining sector. The decline in crude oil prices causes the weakening of the performance of the mining sector. Oil prices touched below the US \$ 30 per barrel, the lowest in 12 years. Even now, oil is still sinking at the US \$ 30 per barrel. When oil prices fall, commodity prices, including mining, will be dragged along. (http://industri.bisnis.com)

According to Platt and Platt in Triswidjanti [1], financial distress is defined as the stage of decreasing conditions that occurred before bankruptcy or liquidation. Financial distress can be influenced by various factors, namely cash flow difficulties, the amount of company debt, and losses experienced by the company in its operational activities. Other factors that can affect financial distress are macroeconomics, such as an increase in loan interest rates or even natural disasters.

The research of Dewi Anggraini and Hadri Mulya [2] used Binary logistic regression analysis method, which found the influence of financial distress prediction on several financial ratios such as: Working Capital to Total Assets; Current Ratio; Book value of equity to Total Liabilities; Total Debt to Total Assets; EBIT to Current Liabilities; and Institutional Ownership.

Fardinal and Gandhy research [3] states that liquidity ratios and solvency ratios have a substantial negative relationship to financial distress, while profitability ratios have a powerfully positive relationship. Mutiara et al. [4] State that there is a significant positive effect on liquidity ratios in predicting financial distress in a company. Vici [5] said that the current ratio has a positive and significant impact on the level of financial distress. Different with what was told According to Rohmadini et al. [6] states that the liquidity ratio there is an insignificant negative effect Current Ratio (CR) to Z-Score (Financial Distress).

Further research by Muhtar et al. [4] shows that profitability ratios have a positive and significant effect on financial distress. According to Aswan [7] said that ROA has a significant positive impact on the level of financial distress. While inversely proportional According to Murni [8] noted that Return on Assets (ROA) has a negative and significant effect on the level of financial distress. 
Previous research on leverage on financial distress. A study conducted by Aswan [9] says that leverage ratios have a positive and significant influence on the level of financial distress. According to Hidayat [10] noted that the leverage ratio has a positive and significant effect on the level of financial distress. But different from what was stated by Darmawan et al. [11] said that there was a negative and significant influence of Debt Ratio (DR) on Z-Score (Financial Distress).

According to Abhinav Kumar Rajverma, Rakesh Arrawatia, Arun Kumar Misra, Abhijeet Chandra [3] entitled "Ownership structure influencing the joint determination of dividends, leverage, and cost of capital" shows that the Dividend Policy Family ownership and firms' average cost of capital has a negative relationship.

Studies on financial distress have been carried out by previous researchers, as conducted by researchers above. From existing studies, researchers want to compare financial ratios. From the differences in the results of previous studies, researchers will review the different variables (inconsistent) in the results of previous researchers, namely analyzing the influence, Current ratio, Return On Assets, Debt Ratio, Dividend Payout Ratio, Price Book Value. Financial distress in the mining sector.

\section{The purpose of this research is to prove empirically about}

- Effect of liquidity on financial distress.

- The impact of profitability on financial distress.

- Impact of Leverage on financial distress

- Impact of Dividend Payout Ratio on financial distress
- $\quad$ Effects of Price Book Value on financial distress

\section{LITERATURE REVIEW}

Financial distress is a stage of decline in the company's financial condition, and if this is allowed to continue, it will cause the company to go bankrupt. Financial distress, according to Murni [8], is a condition where the company's finances are in an unhealthy state of crisis. This financial distress can be seen from various ways, such as the company's declining performance, the company's inability to pay its obligations, the existence of dividend payments termination, cash flow problems faced by the company, liquidity problems, labor layoffs, and other conditions that indicate financial difficulties facing the company.

According to Brigham and Houston [12] states that financial difficulties associated with having a cash flow rate that falls below the level expected by the company. According to Van Horne and Wachowicz [13] revealed that financial difficulties are a risk of the possibility of additional insolvency and variability in profits and decreases arising from the use of the influence of financial leverage. The causes of financial difficulties are usually divided into two, namely internal and external factors of the company, both specifically related directly to the company and general [14].

Altman was the first to find a way to predict company bankruptcy by applying multiple discriminate analyses (MDA) in the development of its model. The model developed by Altman, which became known as Altman's Z-Score, had a high accuracy rate of $95 \%$ for predictions one year before the event.

According to Munawir [14] that the Altman Z-Score analysis model has a variety of models, namely:

1) Original $\mathrm{Z}$ score (Zo) used for public companies has a $94 \%$ prediction a year before bankruptcy and two years after bankruptcy Altman Original Z Score Formula

$$
(\mathrm{Zo}): \mathrm{Zo}=1,2 \cdot \mathrm{X} 1+1,4 \cdot \mathrm{X} 2+3,3 \cdot \mathrm{X} 3+0,6 \cdot \mathrm{X} 4+1,0 \cdot \mathrm{X} 5 \text {, }
$$

2) The $Z$ score for both private and public companies but in variable $X 4$ is revised to book value of the stock market value of capital and total debt. The formula of the revised Altman Z Score

$$
\text { (Za): } \mathrm{Za}=0.717 . \mathrm{X} 1+0.847 . \mathrm{X} 2+3,10 . \mathrm{X} 3+0.42 . \mathrm{X} 4+0.998 . \mathrm{X} 5
$$

The form of the formula used to calculate the Z-Score is as follows (Zo):

$$
(\mathrm{Zo})=1,2 \cdot \mathrm{X} 1+1,4 \cdot \mathrm{X} 2+3,3 \cdot \mathrm{X} 3+0,6 \cdot \mathrm{X} 4+1,0 . \mathrm{X} 5
$$

According to Brigham and Houston [12], liquidity ratios are ratios that show the relationship between cash and other companies' current assets with their current liabilities. To be able to meet its obligations at any time, the company must have the means to pay in the form of current assets whose amounts must be far more significant than the requirements that must be immediately paid in the way of current liabilities. Liquidity itself also refers to the speed and ease of an asset to be converted back into cash or cash [15].

Liquidity itself has value if the more liquid a company is, the less likely the company is experiencing financial difficulties, namely the difficulty in paying debts or buying assets that are needed. Illiquid companies will have a negative impact on the company's finances because debts that cannot be paid overtime will increasingly accumulate both principal 
and interest loans. This can also give lousy judgment from creditors. The current ratio is a ratio that shows how many short-term bills from creditors can be met with current assets that are expected to be converted into cash shortly.

According to Hanafi and Halim [26], this ratio measures a company's ability to generate profitability at a certain level of sales, assets, and share capital. Three rates are often used, namely: profit margin, return on total assets (ROA), and return on equity (ROE). Profit margins calculate the extent to which a company's ability to generate net income at a certain sales level. High-profit margins show the ability of a company to create high profits at a certain level of sales. Return on total assets measures the company's ability to generate net income based on certain asset levels. ROE is also often called ROI. Return on equity aims to measure the company's ability to generate profits based on a certain amount of share capital.

Return on assets (ROA) is the ratio between a company's net profits to total assets. ROA was chosen because ROA can better reflect the earnings of the company than the total assets of the company when compared to other profitability proxies.

According to Hanafi and Halim [16], the ratio measures the company's ability to meet its long-term obligations. This ratio calculates how far the funds provided by creditors if the results of the calculation of high ratios mean the company uses high financial leverage. If the use of significant economic advantage will increase ROA quickly, but vice versa, if sales decrease, ROA will decrease soon as well.

If this situation cannot be handled well by the company, the potential for financial distress is even more significant. Bankruptcy usually begins with a moment of default; this is due to the greater the amount of corporate debt, the higher the probability of financial distress. Leverage Ratio is a ratio used to measure the extent to which a company's assets are financed with debt [17]. This means how the company bears much debt burden compared to its assets. In a broad sense, it is said that the leverage ratio is used to measure the company's ability to pay all of its obligations, both short-term and long-term, if the company is dissolved (liquidated).

Leverage ratio is a ratio used to measure how much a company can fulfill its obligations (pay its debts) if the company is liquidated. According to Brigham and Houston [12], the solvency or leverage ratio used in this study Debt ratio is a debt ratio used to measure the ratio between total debt to total assets. In other words, the Debt ratio is one type of leverage ratio that measures how much the number of company assets financed by debt or capital from creditors. In this study, dividend policy is measured by the Dividend Payout
Ratio (DPR), which is the percentage of profit distributed in the form of cash dividends to shareholders. The size of the dividend payout ratio will affect the investment decisions of shareholders and affect the company's financial condition [18].

According to Mia Lasmi Wardiyah [19] dividend payout ratio part of the income paid as dividends to investors, while other elements that are not distributed will be reinvested into the company. Companies that have high growth rates will have a low dividend payout ratio. Conversely, companies with low growth rates will have a high ratio. Dividend payments are also a company dividend policy: the higher this ratio, the slower or smaller the growth of company revenue.

\section{Framework for Thought and Hypothesis}

According to agency theory assumptions, there are differences in interests between agents and principals that can lead to opportunist actions that harm the company and can result in financial distress. The occurrence of financial distress can be avoided by evaluating the company's internal indicators, including the company's financial ratios.

Financial ratios in predicting financial distress are expressed in a model of the relationship of financial ratios with the use of Z-Score analysis. The Altman ZScore formula is a formula that was coined by Edward I. Altman. The final discriminant function used to predict bankruptcy of the company includes the following financial ratios: working capital / total assets, retained earnings / total assets, earnings before interest and taxes / total assets, market value equity/book value of total debt, sales / total assets.

Several ratios significantly influence the measurement of a company's financial distress prediction.

The higher the level of the company's liquidity ratio, the better the company's financial condition, because it shows that the company is in a liquid state. Vice versa, the higher the liquidity ratio, the less likely the company will experience financial distress, but the liquidity ratio is too high, indicating that the company's working capital is not productive resulting in costs that will reduce the company's profit and will have a positive effect on financial distress.

According to Sidiq [20] Investors in looking for companies to make certain investments, they look for companies that have significant returns because they can benefit the investors and guarantee investors. Therefore this profitability ratio also determines the company's ability to avoid financial distress because if the company can manage the company well, the company will get a good profit, and the risk of financial trouble will decrease as well. Profitability shows how 
much net income earned by the company from each of its assets. High profitability value causes the possibility of companies experiencing deep financial distress.

Leverage describes the extent to which the company's assets are financed with debt, in other words, the area to which the company's ability to pay all of its obligations, both short-term and long-term if the company is liquidated [17]. Financial leverage is used to assess how much the value of debt in financing a company's investment.

According to Aswan's research [21], that leverage has a positive effect on financial distress, while Darmawan's study [11] shows that force affects financial distress.

According to Mia Lasmi Wardiyah [19] dividend payout ratio part of the income paid as dividends to investors, while other elements that are not distributed will be reinvested into the company. Companies that have high growth rates will have a low dividend payout ratio. Conversely, companies with low growth rates will have a high ratio. Dividend payments are also a company dividend policy: the higher this ratio, the slower or smaller the growth of company revenue.

The framework for thinking is as follows:

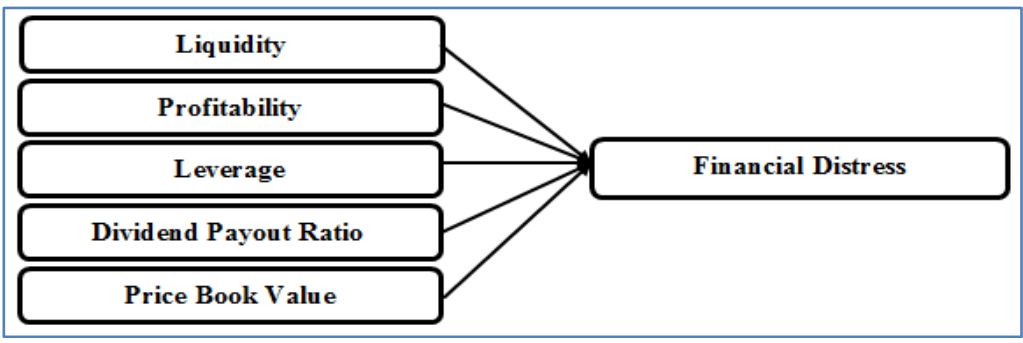

Fig-1: Framework for Thinking

The hypotheses that can be explained are:

$\mathrm{H}_{1}$ : Liquidity affects Financial Distress

$\mathrm{H}_{2}$ : Profitability affects Financial Distress.

$\mathrm{H}_{3}$ : Leverage affects Financial Distress.

$\mathrm{H}_{4}$ : Dividend Payout Ratio affects Financial Distress.

$\mathrm{H}_{5}$ : Price Book Value affects Financial Distress.

\section{RESEARCH METHODS}

The research method used is the causal correlation research method. This analysis analyzes financial performance in predicting Financial Distress. This research was conducted by taking data on annual financial statements of mining companies listed on the Indonesia Stock Exchange. The research data period covering data from 2013 to 2017 is considered sufficient to predict financial distress.

The population in this study are mining sector companies listed on the Indonesia Stock Exchange for the period 2013 - 2017. The community is 44 companies, the number of research samples used by six companies that have met the criteria for the sample criteria is eliminated based on only the amount of Return On Assets that have the results only positive values, for adverse effects are not included in the study sample criteria.

This analysis method uses panel data regression. In conducting analysis and testing EViews 9. computer program tools are used. Multiple Linear Regression, which will be simulated in this section, uses the Ordinary Least Squares (OLS) approach. The explanation will be divided into 4 (four) stages, namely:
1) Data Preparation (Tabulation of Data) 2) Estimation of Linear Regression Models (Multiple) 3) Classical Assumptions Testing 4) Goodness of Fit Models 5) Interpretation of Regression Models Linear (Multiple) Data preparation is intended to input data into the EViews software. After the data is input into the EViews software, the next step is to estimate (estimating) the linear regression model (equation), then proceed with the classical assumption test. Testing classic assumptions are made after the regression model is determined, not before the model is estimated. It is not possible to test classical assumptions before the regression model has been determined because testing of classical hypotheses, which includes normality, heteroscedasticity, and autocorrelation, requires residual model data obtained after the model is formed. If the model created does not meet the classical assumptions required, a modification/transformation/healing of the data or regression model is needed. This section will discuss solutions that must be taken if the classical assumptions are not met in the linear regression model, especially heteroscedasticity. The final stage of this section will explain how to look at the feasibility of the model and interpret the model formed.

\section{RESEARCH RESULT Fixed Effect Model}

The Fixed Effect Model is to estimate panel data using the Dummy variable to explain the differences in intercepts. This model assumes that the regression coefficient (slope) remains between companies and between time. The results of the regression using the Fixed Effect model are as follows: 
Table-1: Fixed Effect Model

\begin{tabular}{|c|c|c|c|c|}
\hline \multicolumn{5}{|c|}{ Dependent Variable: Z_SCORE } \\
\hline \multicolumn{5}{|c|}{ Method: Panel Least Squares } \\
\hline \multicolumn{5}{|c|}{ Date: $10 / 02 / 19$ Time: $22: 15$} \\
\hline \multicolumn{5}{|c|}{ Sample: 20132017} \\
\hline \multicolumn{5}{|l|}{ Periods included: 5} \\
\hline \multicolumn{5}{|c|}{ Cross-sections included: 6} \\
\hline \multicolumn{5}{|c|}{ Total panel (unbalanced) observations: 27} \\
\hline Variable & Coefficient & Std. Error & t-Statistic & Prob. \\
\hline $\mathrm{C}$ & 2.446419 & 0.869840 & 2.812494 & 0.0125 \\
\hline $\mathrm{CR}$ & 0.465977 & 0.161523 & 2.884889 & 0.0108 \\
\hline ROA & 12.37132 & 2.530330 & 4.889211 & 0.0002 \\
\hline DR & -0.278711 & 1.688955 & -0.165020 & 0.8710 \\
\hline DPR & -0.374357 & 0.524499 & -0.713743 & 0.4857 \\
\hline PBV & -2.804307 & 8.445607 & -0.331544 & 0.7445 \\
\hline & \multicolumn{3}{|c|}{ Effects Specification } & \\
\hline \multicolumn{5}{|c|}{ Cross-section fixed (dummy variables) } \\
\hline R-squared & 0.935006 & \multicolumn{2}{|c|}{ Mean dependent var } & 4.089158 \\
\hline Adjusted R-squared & 0.894385 & \multicolumn{2}{|c|}{ S.D. dependent var } & 1.643160 \\
\hline S.E. of regression & 0.534000 & \multicolumn{2}{|c|}{ Akaike info criterion } & 1.874726 \\
\hline Sum squared resid & 4.562502 & \multicolumn{2}{|c|}{ Schwarz criterion } & 2.402660 \\
\hline Log likelihood & -14.30880 & \multicolumn{2}{|c|}{ Hannan-Quinn criter. } & 2.031709 \\
\hline F-statistic & 23.01783 & \multicolumn{2}{|c|}{ Durbin-Watson stat } & 2.846891 \\
\hline Prob(F-statistic) & 0.000000 & & & \\
\hline
\end{tabular}

Based on the results of the TABLE Model Fix Effect above can be seen with the following equation: $Z$ score: C 0.465977 CR + 12.37132 ROA -0.278711 DR - 0.374357 DPR -2.804307 PBV

\section{The following equation can be explained}

a. Constant of 2.446419, meaning that if CR. ROA, DR, DPR, and PBV of 0, the Z Score of 2.446419.

b. The coefficient value of the $\mathrm{CR}$ variable of 0.465977 indicates that if the CR variable increases by one unit, it will increase the Financial distress (Z Score) by 0.465977 times, assuming the other independent variables are constant.

c. The coefficient value of the ROA variable is 12.37132, indicating that if the ROA variable increases by one unit, it will increase the Financial distress (Z Score) by 12.37132 assuming the other independent variables are constant.

d. The coefficient value of the DR variable is 0.278711 , indicating that if the DR variable increases by one unit, it will increase the Financial distress ( $Z$ Score) by -0.278711 , assuming the other independent variables are constant.

e. The coefficient value of the DPR variable is 0.374357, indicating that if the DPR variable increases by one unit, it will increase the Financial distress ( $\mathrm{Z}$ score) by -0.374357 assuming the other independent variables are constant.

f. The coefficient value of the PBV variable is 2.804307, indicating that if the PBV variable increases by one unit, it will increase the Financial distress ( $\mathrm{Z}$ score) by -2.804307 , assuming the other independent variables are constant.

Based on the results of the calculation of the fix affect model above, the results are obtained:
a. CR affects financial distress
b. ROA affects financial distress
c. DR does not affect financial distress
d. IC does not affect financial distress
e. DPR does not influence financial distress
f. PBV does not affect financial distress

Declared significant, assuming an alpha value of 0.05 or $5 \%$, that researchers use with a $95 \%$ confidence level where the probability value $<\alpha(0.05)$ is declared significant if the probability value $>\alpha(0.05)$ can be maintained no effect on the variables studied.

\section{Random Effect Model}

The Random Effect Model is a regression method that estimates panel data by calculating errors from a regression model with the Generalized Least Square method. 
Table-2: Random Effect Model

\begin{tabular}{|c|c|c|c|c|}
\hline \multicolumn{3}{|c|}{ Dependent Variable: Z_SCORE } & & \\
\hline \multicolumn{5}{|c|}{ Method: Panel EGLS (Cross-section random effects) } \\
\hline \multicolumn{5}{|c|}{ Date: $10 / 02 / 19$ Time: $22: 16$} \\
\hline \multicolumn{5}{|l|}{ Sample: 20132017} \\
\hline \multicolumn{5}{|l|}{ Periods included: 5} \\
\hline \multicolumn{5}{|c|}{ Cross-sections included: 6} \\
\hline \multicolumn{5}{|c|}{ Total panel (unbalanced) observations: 27} \\
\hline \multicolumn{5}{|c|}{ Swamy and Arora estimator of component variances } \\
\hline Variable & $\begin{array}{c}\text { Coefficien } \\
\mathrm{t}\end{array}$ & Std. Error & t-Statistic & Prob. \\
\hline $\mathrm{C}$ & 2.133182 & 0.602120 & 3.542788 & 0.0019 \\
\hline CR & 0.398838 & 0.140493 & 2.838851 & 0.0098 \\
\hline ROA & 16.79034 & 1.841462 & 9.117938 & 0.0000 \\
\hline DR & -0.683203 & 0.738052 & -0.925683 & 0.3651 \\
\hline DPR & 0.224765 & 0.365984 & 0.614137 & 0.5457 \\
\hline \multirow[t]{3}{*}{ PBV } & -3.664307 & 5.885607 & -0.622556 & 0.5403 \\
\hline & \multicolumn{2}{|c|}{ Effects Specification } & & \\
\hline & & & S.D. & Rho \\
\hline \multicolumn{3}{|l|}{ Cross-section random } & $1.93 \mathrm{E}-06$ & 0.0000 \\
\hline \multicolumn{3}{|l|}{ Idiosyncratic random } & 0.534000 & 1.0000 \\
\hline & \multicolumn{2}{|c|}{ Weighted Statistics } & & \\
\hline R-squared & 0.649964 & \multicolumn{2}{|c|}{ Mean dependent var } & 4.089158 \\
\hline Adjusted R-squared & 0.566622 & \multicolumn{2}{|c|}{ S.D. dependent var } & 1.643160 \\
\hline S.E. of regression & 1.081716 & \multicolumn{2}{|c|}{ Sum squared resid } & 24.57229 \\
\hline F-statistic & 7.798763 & \multicolumn{2}{|c|}{ Durbin-Watson stat } & 0.683303 \\
\hline \multirow[t]{2}{*}{ Prob(F-statistic) } & 0.000278 & & & \\
\hline & \multicolumn{2}{|c|}{ Unweighted Statistics } & & \\
\hline R-squared & 0.649964 & \multicolumn{2}{|c|}{ Mean dependent var } & 4.089158 \\
\hline Sum squared resid & 24.57229 & \multicolumn{2}{|c|}{ Durbin-Watson stat } & 0.683303 \\
\hline
\end{tabular}

Source: data processed using Eviews 9, 2019

Based on the results of table 2 Random Effect above, the following equation can be obtained:

Z Score: C 0.398838 CR + 16.79034 ROA - 0.683203 DR + 0.224765 DPR -3.664307 PBV

The following equation can be explained

a. A constant of 2.133182, meaning that if CR. ROA, DR, DPR, and PBV of 0, the Financial distress ( $\mathrm{Z}$ Score) of 2,133182.

b. The coefficient value of the $\mathrm{CR}$ variable of 0.398838 indicates that if the CR variable increases by one unit, it will increase the Financial distress ( $\mathrm{Z}$ Score) of 0.398838 , assuming the other independent variables are constant.

c. The coefficient value of the ROA variable of 16.79034 indicates that if the ROA variable increases by one unit, it will increase the Financial distress ( $Z$ Score) by 16.79034 , assuming the other independent variables are constant.

d. The coefficient value of the DR variable is 0.6683203 , indicating that if the DR variable increases by one unit, it will increase the Financial distress (Z Score) by -0.668203 assuming the other independent variables are constant.

e. The coefficient value of the DPR variable of 0.224765 indicates that if the DPR variable increases by one unit, it will increase the Financial distress ( $\mathrm{Z}$ Score) of 0.224765 , assuming the other independent variables are constant. f. PBV coefficient value of -3.664307 indicates that if PBV variable increases by one unit, it will increase the Financial distress ( $Z$ Score) of -3.664307, assuming the other independent variables are constant.

Based on the calculation results of the random effect model above, the results are obtained:
a. CR affects financial distress
b. ROA affects financial distress
c. DR does not affect financial distress
d. IC does not affect financial distress
e. DPR does not influence financial distress
f. PBV does not affect financial distress

Declared significant, assuming an alpha value of 0.05 or $5 \%$, that researchers use with a $95 \%$ confidence level where the probability value $<\alpha(0.05)$ is declared significant if the probability value $>\alpha(0.05)$ can be maintained no effect on the variable under study.

\section{Hypothesis Testing Results}

Hypothesis testing is done by conducting a t-test or commonly referred to as a partial test. It aims to prove whether each independent variable in the study 
influences the dependent variable. The provisions in this test are if the probability of each independent variable in this study is less than 0.05 , then $\mathrm{H} 0$ is rejected, and $\mathrm{H} 1$ is accepted. Still, if the probability of each independent variable in this study is more significant than 0.05 , then $\mathrm{H} 0$ is approved, and $\mathrm{H} 1$ rejected, which means that the independent variable does not affect the dependent variable. Based on the Fix Effect test table that contains the results of the t-test by looking at the t-statistic and probability values can be explained as follows:

1. Current Ratio (CR)

According to table 1 , the $\mathrm{CR}$ variable obtained the value of $t$ count 2.884889 with a probability value of 0.0108 , which is smaller than the significance level of 0.05 , then $\mathrm{HO}$ is rejected, and $\mathrm{H} 1$ is accepted. This shows that the CR variable affected the Financial Distress of the mining sector in the 2013-2017 period.

2. Return On Assets (ROA)

According to table 1, the ROA variable is obtained $t$ value of 4.889211 with a probability value of 0.0002 smaller than the significance level of 0.05 , then $\mathrm{H} 0$ is rejected, and $\mathrm{H} 1$ is accepted. This shows the ROA variable affects the Financial Distress of the mining sector in the period 2013-2017.

3. Debt Ratio (DR)

According to table 1, the DR variable obtained by the $t$ value of -0.165020 with a probability value of 0.8710 is higher than the significance level of 0.05 , then $\mathrm{H} 0$ is accepted, and $\mathrm{H} 1$ is rejected. This shows that the DR variable has no effect on the Financial Distress of the mining sector in the 2013-2017 period.

4. Dividend Payout Ratio (DPR)

According to table 1, the DPR variable obtained by the $t$ value of -0.713743 with a probability value of 0.4857 is higher than the significance level of 0.05 , then H0 is accepted, and H1 is rejected. This shows that the DPR variable does not affect the Financial Distress of the mining sector in the 2013-2017 period.

5. Price Book Value (PBV)

According to table 1, the PBV variable obtained by the $t$ value of -0.331544 with a probability value of 0.7445 is higher than the significance level of 0.05 , then $\mathrm{H} 0$ is accepted, and $\mathrm{H} 1$ is rejected. This shows that the PBV variable does not affect the Financial Distress of the mining sector in the period 20132017.

\section{Determination Coefficient Test $\left(\mathbf{R}^{2}\right)$}

The coefficient of determination $\left(\mathrm{R}^{2}\right)$ is to measure the ability of the model in explaining the variation of the dependent variable. The coefficient of determination is used to determine the effect of independent variables, namely CR, ROA, DR, DPR, and PBV on the dependent variable, namely Financial distress ( $\mathrm{Z}$ Score). From the data processing, it is obtained the adjusted determination coefficient test results $\left(\mathrm{R}^{2}\right)$ as follows:

Based on the adjusted R-square value on the Fix Effect test results of $89.43 \%$ it can be interpreted that the CR, ROA, DR, DPR, and PBV can explain its relationship to Financial distress (Z Score), while other variables outside the research model explain the rest of $10.5 \%$.

From the statistical test results of panel data regression analysis using Eviews 9 software, t-test was obtained as follows:

\section{Effect of Current Ratio ( $\left.X_{1}\right)$ on Financial Distress ( $Z$ Score) (Y)}

Based on the results of the above output, it can be seen the coefficient value is 0.465977 ; the statistical $\mathrm{t}$ value is 2.884889 with a probability of 0.465977 $<0.05$, then $\mathrm{H} 0$ is rejected, and $\mathrm{Ha}$ is accepted, Current Ratio affects the Financial Distress variable ( $\mathrm{Z}$ Score) on the mining sector companies listed on the Indonesia Stock Exchange in the year 2013-2017. So that in this study, H1 was accepted.

Current Ratio is a ratio that shows the relationship between cash and other company's existing assets with current liabilities [12]. The current ratio itself also refers to the speed and ease of an asset to be converted back into cash or cash. In existing assets, there are trade receivables and inventories that will be used to pay the company's current debts. Each company requires different periods to convert trade payables and inventories into cash to meet its current debt. Because it aims to measure the number of liquid assets when compared with the overall assets owned, this thinking is based on Altman's observations of the current ratio, which is not useful for predicting bankruptcy or financial distress. The results of this study are supported by research conducted by Putri and Merkusiwati [22], which states that liquidity (CR) does not have a significant effect on financial distress.

\section{Effect of Return On Assets $\left(X_{2}\right)$ on Financial Distress (Z Score) (Y)}

Based on the results of the output above, it can be seen the coefficient value is 12.37132 ; the statistical $\mathrm{t}$ value is 4.889211 with a probability of $0.0002<0.05$. It means that in this research, $\mathrm{HO}$ is rejected, and $\mathrm{Ha}$ is accepted, where every one variable Return on Assets has a significant effect on Financial Distress (Z Score) on mining sector companies listed on the Indonesia Stock Exchange in 2013-2017. So that in this study, H2 was received.

The results of profitability research using ROA show results that affect the $\mathrm{Z}$ score. This means that any change in ROA increase will reduce the level of financial distress. The greater the value of ROA means, the higher the profit generated; the higher the $\mathrm{Z}$ score will be. A high $\mathrm{Z}$ score can say that the company is safe 
from the Financial Distress zone (financial difficulties). This will attract investors to invest so that the demand for company shares will increase. High profitability also shows the company can use assets and investments owned to generate profits so that more effective and efficient management of company assets can reduce the costs incurred by the company. The results of this study are consistent with the results of research conducted by Aswan [2] and Zultilisna [7], which states that Return On Assets (ROA) has a positive and significant effect on Financial Distress.

\section{Impact of Debt Ratio $\left(\mathbf{X}_{3}\right)$ on Financial Distress ( $Z$ Score) (Y)}

Based on the output above the coefficient value for the Debt Ratio variable is -0.278711 , the tstatistic value is -0.165020 with a probability of $0.8710>0.005$ then H0 is accepted, and Ha is rejected, meaning that the Debt Ratio does not affect the Financial Distress ( $Z$ Score) of the mining sector companies that listed on the Indonesia Stock Exchange in 2013-2017. Debt Ratio is a ratio used to measure the extent to which a company's assets are financed with debt [17]. This means how the company bears much debt burden compared to its assets. The value of a small Debt Ratio does not fully guarantee a company is exposed to financial distress. Because with a low Debt Ratio value indicates that not all of the company's capital assets are financed from debt and management can manage a small loan to manage assets into profit, so that the higher amount of assets owned by the company comes from its capital compared to the total debt it has. According to Altman Z-score [23], the parameters in formula X4 are useful for measuring the level of leverage of a company. If the company has too much debt, it will be dangerous for the survival of the company, especially if behind it there is interest to be paid. This result is reinforced by Arwinda Putri [22] who stated that Leverage (DR) does not affect the likelihood of the occurrence of Financial Distress ( $\mathrm{Z}$ Score)

\section{Effect of Dividend Payout Ratio $\left(\mathrm{X}_{4}\right)$ on Financial Distress (Z Score) (Y)}

Based on the results of the output above the coefficient value for the Dividend Payout Ratio variable of 1.703604 , the t-statistic amount of -0.713743 with a probability of $0.4857>0.005$ then $\mathrm{H} 0$ is accepted, and $\mathrm{Ha}$ is rejected, the Payout Ratio Dividend does not affect the Financial Distress ( $Z$ Score) of the mining sector companies listed on the Indonesia Stock Exchange in 2013-2017. This means that every substantial increase in Dividend Payout Ratio in the company, the higher the value of the $\mathrm{Z}$ score, says the smaller the level of Financial Distress that occurs in the company. These results are consistent with what was revealed by Saifi [8] with the high share ownership by institutional investors; this institutional shareholder can replace or strengthen the monitoring function of management in the company. This is due to the higher institutional ownership, institutional shareholders can exercise more supervision over administration in carrying out their operational activities, and there is transparency in the use of company funds which can be audited by institutions/business entities and centralized. So with a significant level of trust will be avoided from conditions of financial distress or Financial Distress. The results of this study are consistent with the results of research conducted by Merkusiwati [22], which states that institutional ownership (KI) does not affect Financial Distress (Z Score).

\section{Impact of Price Book Value $\left(\mathrm{X}_{5}\right)$ on Financial Distress (Z Score) (Y)}

Based on the results of the output above the coefficient value for the Price Book Value variable of 2.804307 , the t-statistic amount of -0.331544 with a probability of $0.7445>0.005$ then $\mathrm{H} 0$ is accepted, and $\mathrm{Ha}$ is rejected, the Price Book Value does not affect the Financial Distress ( $\mathrm{Z}$ Score) of the mining sector company recorded

\section{CONCLUSIONS}

1. The current Ratio affects the Financial Distress variable ( $\mathrm{Z}$ Score) on mining sector companies listed on the Indonesia Stock Exchange in 20132017. So that in this study, H1 was accepted. Because it aims to measure the number of liquid assets when compared with the overall assets owned. This thinking is based on Altman's observations of the current ratio, which is not suitable for predicting bankruptcy or financial distress.

2. The results of profitability research using ROA show results that affect the $\mathrm{Z}$ score. This means that any change in ROA increase will reduce the level of financial distress. The greater the value of ROA means, the higher the profit generated; the higher the $\mathrm{Z}$ score will be. A high $\mathrm{Z}$ score can say that the company is safe from the Financial Distress zone (financial difficulties). This will attract investors to invest so that the demand for company shares will increase.

3. Debt Ratio has no effect on Financial Distress $(Z$ Score) on mining sector companies listed on the Indonesia Stock Exchange in 2013-2017. Debt Ratio is a ratio used to measure the extent to which a company's assets are financed with debt (Kasmir, 2014). This means how the company bears much debt burden compared to its assets. The value of a small Debt Ratio does not fully guarantee a company is exposed to financial distress.

4. Dividend Payout Ratio has no effect on Financial Distress (Z Score) on mining sector companies listed on the Indonesia Stock Exchange in 20132017. This means that every substantial increase in Dividend Payout Ratio in the company, the higher the value of the $\mathrm{Z}$ score, says the smaller the level of Financial Distress that occurs in the company. 
5. Price Book Value has no effect on Financial Distress (Z Score) on mining sector companies listed on the Indonesia Stock Exchange in 20132017. The market reaction cannot predict Financial Distress.

\section{SUGGESTION}

This research can provide additional information and theory development related to Financial Performance Analysis in Predicting Mining Company Financial Distress. It also refers to financial accounting, agency theory, and Financial Statement Analysis.

This research is expected to help investors in making investment decisions. Also, mining companies are also likely to be able to maintain and increase trust.

\section{REFERENCES}

1. Triswidjanti, M. S., \& Nuzula, N. F. (2017). Implementasi o-score model untuk memprediksi financial distress perusahaan (Studi pada Perusahaan Manufaktur Sub Sektor Tekstil dan Garmen yang Terdaftar di Bursa Efek Indonesia Periode 2011-2015). Jurnal Administrasi Bisnis, 50(1), 126-135.

2. Anggraini, D., \& Mulya, H. (2017). Financial Distress Prediction in Indonesia Companies: Finding An Alternative Model.RJOAS,1(61).

3. Gandhy, F. (2019). Analysis of Financial Ratio to Predict Financial Distress Conditions (Empirical Study on Manufacturing Companies listed on the Indonesia Stock Exchange for 2014-2017). IJBMI, PP 27-34.

4. Muhtar, M. (2017). Pengaruh Kinerja Keuangan Terhadap Terjadinya Kondisi Financial Distress Pada Perusahaan Telekomunikasi Di Indonesia. Journal bisnis manajemen dan informatika, 167184.

5. Ardian, A. V. (2016). Pengaruh Rasio Likuiditas, Rasio Leverage, Rasio Aktifitas Dan Rasio Profitabilitas Terhadap Financial Distress (pada perusahaan manufaktur yang terdaftar di Bursa Efek Indonesia periode tahun 2013-2015). E-Jurnal Universitas Pandanaran Semarang, 3-15.

6. Rohmadini, A. M. (2018). Pengaruh Profitabilitas, Likuiditas Dan Leverage Terhadap Financial Distress (Studi Pada Perusahaan Food \& Beverage Yang Terdaftar Di Bursa Efek Indonesia Periode 2013-2016). Journal Administrasi Bisnis, 11-19.

7. Joffani, R. (2017). Analisis Pengaruh Likuiditas, Leverage dan Operating Capacity terhadap financial distress pada perusahaan pertambangan. e-proceeding of Management Vol.4, No.3 Desember 2017, 2648-2653.
8. Murni, M. (2018). Analisis Faktor-Faktor Yang Mempengaruhi Tingkat Financial Distress Pada Perusahaan Manufaktur Yang Terdaftar Di Bei Tahun 2010-2014. Jurnal Akuntansi Dan Bisnis, 74-83.

9. Chrissentia, T. (2018). Analisis Pengaruh Rasio Profitabilitas, Leverage, Likuiditas, Firm Age, Dan Kepemilikan Institusional Terhadap Financial Distress (Pada Perusahaan Jasa Non Keuangan yang terdaftar di Bursa Efek Indonesia Tahun 2014-2016). E-Journal Akuntansi, 45-61.

10. Hidayat, M. A. (2014). Prediksi Financial Distress Perusahaan Manufaktur Di Indonesia. Diponegoro Journal Of Accounting, 1-11.

11. Darmawan, D., Kartawinata, H., \& Astorina, W. (2018). Development of Web-Based Electronic Learning System (WELS) in Improving the Effectiveness of the Study at Vocational High School" Dharma Nusantara". JCS, 14(4), 562-573.

12. Brigham, E. F. (2014). Dasar-dasar Manajemen Keuangan. Jakarta: Salemba Empat.

13. Wachowich, J. V. (2014). Prinsip-prinsip manajemen keuangan (Edisi 13- buku 1 ed.). Jakarta: Salemba Empat.

14. Munawir. (2012). Analisa Laporan Keuangan. Cetakan Kelima. Yogyakarta: PT. Raja Grafindo.

15. Wahyu, H. M. (2014). Prediksi Financial Distress (Perusahaan Manufaktur Di Indonesia Periode 2008-2012). Diponegoro Journal Of Accounting, 111.

16. Hanafi, M. M. (2014). Analisis Laporan Keuangan. Edisi tujuh, UPP AMP YKPN. Yogyakarta.

17. Kasmir. (2014). Analisis Laporan Keuangan. Jakarta: Rajawali Pers.

18. Rachmat, A., Huda, N. M., \& Anita, S. (2019). Predictive Analytic Klasifikasi Penentuan Tarif Sewa Bus. Jurnal Sistem Cerdas, 2(2), 135-149.

19. Wardiyah, M. L. (2017). Manajemen Pasar Uang dan Pasar Modal.

20. Helena, S. (2018). Pengaruh Corporate Governance Terhadap Financial Distress (Studi Pada Perusahaan Transportasi Yang Terdaftar di Bursa Efek Indonesia Periode 2013-2016). Jurnal Administrasi Bisnis, 143-152.

21. Fatmawati, V. (2017). Pengaruh Likuiditas, Leverage, Aktivitas Dan Profitabilitas Dalam Memprediksi Financial Distress. Jurnal Ilmu Dan Riset Akuntansi, 1-19.

22. Putri, N. W. (2014). Pengaruh mekanisme corporate governance, likuiditas, leverage, dan ukuran perusahaan pada financial distress. $E$ Journal Akuntansi, 15-16.

23. Febriani, M. U. (2013). Analisis Z-Score Untuk Memprediksi Financial Distress Pada Perusahaan Pulp And Paper . Jurnal Ilmu dan Riset Akuntansi, $1-22$. 